\title{
Consumer Purchasing Decision Improvement Model through Brand Image, Religiosity, Brand Ambassador and Brand Awareness
}

\author{
Wuryanti Kuncoro $^{1}$, \& Hanifah Azhar Windyasari ${ }^{2}$ \\ ${ }^{1}$ Dept. of Management, Faculty of Economics, Universitas Islam Sultan Agung Semarang, Indonesia \\ Correspondence: Wuryanti Kuncoro, Dept. of Management, Faculty of Economics, Universitas Islam Sultan \\ Agung Semarang, Indonesia.
}

Received: June 4, 2021

doi:10.5539/ibr.v14n8p42
Accepted: June 24, $2021 \quad$ Online Published: July 9, 2021

URL: https://doi.org/10.5539/ibr.v14n8p42

\begin{abstract}
In several studies, theoretically, companies that have good brand ambassadors will produce good purchasing decisions. However, empirically, it does not guarantee that brand ambassadors are able to produce good purchasing decisions. This gap is interesting to study in depth. Based on theoretical studies and according to the viewpoint of previous research, the concept of brand awareness is expected to be a solution in overcoming research gaps in brand ambassadors and consumer purchasing decisions. Companies that use brand ambassadors that generate good brand awareness are companies that are able to increase consumer purchasing decisions. For this reason, 150 Tokopedia users in Central Java were researched and tested the linkages between research variables. This phenomenon study is expected to contribute to the development of science, especially marketing management.
\end{abstract}

Keywords: brand image, religiosity, brand ambassador, brand awareness, consumer purchasing decision

\section{Introduction}

Recruiting artists as brand ambassadors is one of the most commonly used marketing tools in companies and is not a new strategy. This strategy has long been used by several companies and is effective in introducing products to the public. According to a simple explanation from (Doucett, 2008) in his book, it is emphasized that a brand ambassador is someone who has a passion for a brand, wants to introduce and provide information about the brand. The use of brand ambassadors is carried out by companies to influence or encourage consumers to use these products. The use of brand ambassadors usually uses well-known celebrities (Royyan, 2004). Because of research on Social Media Revolution, Qualman (2010) showed data that 78\% of people trust other people's recommendations more than ads. Currently, technological developments have a broad impact on various aspects, including the development of the business and marketing world. The internet has become one of the main tools for marketers in an effort to promote their products. Due to this phenomenon, internet users are growing very rapidly and have become the lifestyle of today's society. One of the fastest growing internet systems is an electronic sales system (e-commerce) which is very popular among its users.

Online shopping has now become a new hobby favored by consumers ranging from children, adolescents to adults. According to hootsuite data in 2018, Indonesia ranks in the top ranks of users who are actively shopping online, even above China and Thailand. Tokopedia.com is one of the leading e-commerce sites in Indonesia which was founded on August 17, 2009 with a vision to build a better Indonesia through the internet. Tokopedia is a marketing tool to market or promote their products in online media and become one of the online malls in Indonesia that carries a marketplace business model. Therefore, Tokopedia must pay attention to important factors that can attract internet users to visit and buy at Tokopedia.com. Tokopedia is the number one e-commerce most actively used in Indonesia in 2019. Tokopedia itself is not just looking for ways to attract consumer interest. to access their e-commerce applications. Interest in accessing applications made by consumers as well as consumer decisions to buy a product.

Consumer purchasing decisions for a product greatly affect the welfare of the product Supriyadi et al. (2016). The higher the consumer is involved in searching for product information, the greater the incentive for the consumer to make a purchase. One of the unique ways that Tokopedia has done is hooking up a boy group from South Korea, namely BTS, as Tokopedia's Brand Ambassador. BTS (Bangtan Sonyeondan) or known as Bangtan Boys is a boy group consisting of seven members from South Korea formed by BigHit Entertainment 
and debuted on June 12, 2013. Judging from the high enthusiasm of the Indonesian people towards the popularity of the BTS boy group, it is hoped that this will happen. can have a positive impact and boost Tokopedia's Brand Image. Tokopedia decided to finally recruit BTS to become a Brand Ambassador. By appointing BTS as a Brand Ambassador, it is hoped that it can increase Tokopedia's Brand awareness, so that Tokopedia can be known and always remembered by the public as consumers. Brand awareness plays an important role in consumer buying interest, this is because consumers tend to buy products that are familiar and better known. Brand Awareness can also help consumers identify the brand of a product and make purchase decisions (Percy and Rossiter, 1992). Several studies have stated that brand ambassadors have a positive influence on purchasing decisions, such as in Wang and Hariandja, (2016). However, in Samosir (2016) expressed a different opinion, namely that Brand Ambassador has a negative and significant effect on purchasing decisions. This study will examine the use of the influence of Brand Ambassador, brand image, religiosity, and brand awareness on Tokopedia e-commerce to improve purchasing decisions.

\section{Literature Review}

\subsection{Brand Image and Consumer Purchasing Decision}

Brand is the total accumulation of customer experience Rahi (2015). Brand image has been studied extensively since the 20th century because of its importance in building brand equity (Zhang Yi, 2015). Not much different, Kotler and Keller (2009) define brand image as perceptions and beliefs held by consumers that are embedded in the customer's memory, which is always remembered for the first time when hearing a slogan and embedded in the consumer's mind. In line with the opinion of Supriyadi et al. (2016) which defines brand image as the mass imaging of a product in the minds of consumers. Everyone will have the same image of a brand. Brand image is the result of overall consumer perceptions of products that come from past experiences in using these products (Dwivedi, et. al, 2015). Products that are able to meet consumer needs and even exceed what consumers expect, will then create a positive image that is good for consumers and vice versa, products that are less able to provide satisfaction will certainly create a negative image for consumers (Boxstael, et. al (2014); Latiff, et.al (2016).

Then according to Ryu et al., (2008) brand image is a determinant that affects the subjective perceptions of customers and behavior afterward, and is an extrinsic cue when consumers evaluate a product or service before buying (Zeithaml, 1988). Brand image plays an important role in helping customers decide whether to buy a brand and thus can influence their buying behavior (Bian and Moutinho, 2011). Brand image can also serve as a defensive marketing tool to retain customers thereby encouraging loyalty, especially in a service context where service / company brands are considered to be identical (Sweeney and Swait, 2008). Brand image can also help consumers identify their needs and wants about brands and differentiate brands from other competitors (Anwar et al., 2011). The more beneficial the Brand Image is, the more positive the attitude towards branded products and their attributes (Aghekyan-Simonian et al., 2012). According to Prabowo (2013) the measurement of brand image is subjective, which means that there are no standard provisions in its measurement. Measuring brand image can be done based on the aspects of a brand, namely Strengthness, Uniqueness and Favorable.

Consumer purchasing decision is a process where consumers know a problem, look for information about a product or brand and evaluate how well each alternative can solve the problem, which ultimately leads to a purchase decision (Tjiptono, 2014). According to (Schiffman and Kanuk, 2004) a purchasing decision is the selection of two or more existing alternative options. According to Kotler (2008), a purchase decision is an action by consumers to buy or not to a product. Anwar et al., (2011) argues that a person's buying decision is originally influenced by the environment, culture, family, etc. which will form an attitude for the individual, then make a purchase decision. Not much different from the opinion of Kotler and Amstong (2008) that the purchase decision is a decision process where consumers actually decide to buy one product among a variety of alternative choices. Based on the understanding of the experts above, it can be concluded that a collection of consumer purchasing decisions is one of the concepts of individual, group, and organizational consumer behavior to choose, buy, and use goods, services, ideas or experiences to satisfy their needs and desires so that the final result will be. decide to buy or not.

Kotler and Keller (2007) suggest that there are five stages that consumers go through in the decision-making process, namely problem recognition, information search, alternative evaluation, purchase decisions and post-purchase behavior. The dimensions used to measure purchasing decisions are product selection that includes the level of product needs; brand selection that includes the level of trust, popularity; selection of distributors that include the level of easy access to products and availability; the purchase time and quantity includes the time of purchase rate. Another opinion expressed by (Kotler, 2007) related to measurement for purchase decisions is the belief to buy, consideration in buying and product recommendations. 
Brand Image of a brand in the eyes of consumers is an important element in the process of determining the purchase decision. Marketers must be able to put the brand well in the minds of their consumers. A good brand and product image will encourage potential buyers to buy products to certain brands and not consider other brands (Rommy et al., 2018). A good impression on a brand will appear if the brand is superior, unique, popular, and trustworthy (Fianto et al., 2014). In Wijayanti, et.al (2010) concluded that brand image has a significant influence on purchasing decisions. Similar to previous research conducted by Permana (2016) and Fahreza (2018), brand image has a positive and significant impact on consumer purchasing decisions. Similar to (Dwivedi, et. al, 2015). a positive brand image will have a positive effect on purchasing decisions. The better the brand image created by the company, the higher the level of decision making to buy. Based on previous research, the first hypothesis is:

\section{H1: Brand Image has a significant effect on Consumer Purchasing Decision}

\subsection{Religiosity and Consumer Purchasing Decision}

Religiosity is a complex concept that is often seen as a personal phenomenon, including belief in god and a commitment to follow the principles believed to be established by God (Esso and Dibb, 2004). This term includes a large enough reason such as behavior, attitudes, beliefs, feelings and experiences. And has been defined as a multidimensional concept that measures indicators of belief in attitudes and behavior (Ansari, et. al, 2008). Religiosity is a multidimensional and complex concept, so definitions can vary based on the religion being assessed. The terms religion and religiosity are used interchangeably to define the same concept in recent literature (Hill and Pargament, 2003). Religion refers to a person's belief in absolute permanence and the inherent quality of truth from the teachings and scriptures of the religion.

According to McDaniel and Burnett (1990) religiosity is belief in God accompanied by a commitment to follow the principles believed to be established by Razzaque, et. al (2013) define religiosity as the extent to which a person believes in God and the values and ideals of his religion. In fact, it refers to a person's commitment to their religious teachings (Engelland, 2014). In addition, religiosity is defined as the extent to which a person is committed to their religion and is reflected in the attitudes and behavior of the individual (Hill and Pargament, 2003). However, there are still many researchers who tend to define it in terms of values, sacred objects, beliefs, rituals, prayers, norms, what to do and what not. Religion can be considered as a very important indicator in any decision-making process, where it is the foundation that directs a person to behave legally and ethically (Ahmad et al., 2015).

From an Islamic perspective, religiosity is a commitment to the foundations of Islam both empirically and theoretically through fulfilling the rights of Allah SWT, protecting the rights of others, following His orders, avoiding evil deeds and performing worship (Al-Goaib, 2003). According to Shukor and Jamal (2013) the measurement of a Muslim's religiosity must include two important aspects, namely the relationship with Allah SWT (Hablum MinAllah) and the relationship with others (hablum Minannas). Other indicators according to research by Rahman et al (2015) are belief, experience, worship and science. Faith, namely the relationship with Allah SWT, the Prophet and the angels. Experience, namely the feeling of being afraid of violating the prohibitions set by Allah SWT and relating to attitudes in society or daily life. Worship, which is carrying out the prescribed worship. Science, includes a person's knowledge of Islamic teachings. Religion can be considered as a very important indicator in any decision-making process, where it is the foundation that directs a person to behave legally and ethically. In previous studies, it has been observed that religiosity can play a key role in an individual's decision making (Lau, 2010). According to Elaziz and Kurt (2017) religion influences consumer decision making when buying a product or service. Furthermore, Alam et al., (2011) claim that religion is one of the components of subculture besides nationality, race and geographic area which has the most influential determinants of human behavior. A number of studies have confirmed that consumers have different levels of religiosity in buying behavior. In addition, religiosity affects several aspects of the consumer's lifestyle which in turn can influence choices. Consumers with a high level of religiosity will be more sensitive than those with low religiosity (Aliman, et.al, 2018). The direct relationship between religiosity and green product purchasing decisions has also been explored by previous researchers (Kalamas et al., 2014). Based on previous research giving birth to the hypothesis:

\section{H2: Religiosity has a positive and significant effect on Consumer Purchasing Decision}

\subsection{Brand Ambassador, Brand Awareness, and Consumer Purchasing Decision}

Today's marketing through brand ambassadors or celebrities may be considered a ubiquitous feature (Kurzman et al., 2007). The purpose of companies using a brand ambassador is to influence or invite consumers to use a product and the selection of a brand ambassador itself is usually a famous celebrity (Prawira et al, 2012). Brand 
ambassadors have developed through social media technology because social media platforms allow for "the transformation of monologue broadcasts into social dialogue" (Botha and Mills, 2012). A brand ambassador is someone who is passionate about an organization or its brand and is involved in activities. These activities often involve social media that give brand meaning to consumers (Ambroise, Pantin-Shoier, Valette-Florence, Albert, 2014). Prawira (2012) explains that a Brand Ambassador is someone who presents the best image of a product. Brand ambassadors are usually referred to as product ambassadors who serve as communicators and have an important role in conveying messages about a product that will be offered to consumers. Not much different as the opinion (Shimp, 2003).

Brand Ambassador is an advertising supporter or known as an advertising star who supports a product to be advertised. These Brand Ambassadors are also expected to become brand spokespersons to quickly stick to consumers' minds. With the decision to choose the right Brand Ambassador, companies can build trust and higher customer relationships (Ambroise et al., 2014). Brand ambassadors are able to embody the human component of the brand's value structure (Chernatony, 2001), and show their traits that can be imitated because of their influence status. In appointing someone to become a brand ambassador there are several important indicators that need to be considered. Brand ambassadors can be seen using the VisCAP model. VisCAP consists of 4 elements, namely Visibility, Credibility, Attraction and Power. The VisCAP model is used to evaluate potential endorsers based on audience perceptions of these endorsers. The VisCAP model was developed by Rossiter and Percy (1987).

Brand Awareness is a description of the existence of a brand that is in the minds of consumers. If consumers have seen or heard about a brand, they can tell the brand correctly Brewer and Zhao (2010). According to Liu and Aaker (2008), brand awareness is the ability of customers to recognize or remember that a brand is included in a particular product. Brand awareness is a basic component of brand equity (Yuan et al., 2014). A brand can be said to have equity if consumers recognize and remember a product brand outside of other products. In the opinion of Valkenburg and Buijzen (2005) brand awareness is individual knowledge about a particular brand and also involves brand names, logos, symbols and so on to certain brand associations. Brand awareness is also related to impressions that have been stored in memory which reflect the ability of consumers to remember or recognize brands in different conditions (Habibah \& Sumiati, 2016). According to Karam and Saydam (2015), brand awareness has turned into an important variable that affects customer perceptions of a brand. Furthermore, according to Homburg et al., (2010) brand awareness refers to the capacity of decision makers to distinguish or remember a brand. The success of building brand awareness depends on how well consumers understand brands designed to meet their needs Wulandari, et. al (2012).

Brand awareness also plays an important role in influencing customers to make decisions Berryman and Kavka (2017). Includes individual recognition, knowledge domination and brand recall (Kim \& Kang, 2008). Just as the opinion of Shabbir, et. al (2017), brand awareness plays a major role in consumer decision making, because the higher the level of brand awareness, the product or brand will become part of a series of consumer considerations. Because in general, consumers tend to buy products with brands that are known for their convenience, safety and so on. A product that is easy to remember, accepted, and liked in the marketplace will lead to consumer purchasing decisions. The higher the level of brand awareness (brand awareness) attached to the minds of consumers, the more likely the brand is considered in consumer purchasing decisions. Similar to Tsiotsou and Wirtz (2015), a brand that has a strong presence in the minds of consumers, especially the brand that has provided very high satisfaction to consumers, of course it will be very well known and remembered by consumers so that consumers decide to buy, and vice versa if a brand has not yet. known to consumers it actually makes consumers disappointed, of course the level of brand awareness in consumers will be very low so that consumers will not decide to buy. This is in accordance with previous research conducted by Berryman and Kavka (2017), that brand awareness influences purchasing decisions.

Creative strategies undertaken by companies to increase interest and position a product towards consumers are usually through the appointment of brand ambassadors. A brand ambassador is someone who is known to the public for his achievements or popularity in a field. Brand ambassadors deliver advertising messages that are meant to attract attention and thus influence target consumers. This brand ambassador can then become a bridge between companies and consumers because consumers certainly trust the voice of the consumer more than the voice of the company. With the existence of brand ambassadors, namely artists who are known to the public at large to promote these products, this is a special attraction for consumers to follow everything that the artist does, so that consumers will make purchase decisions. Previous research conducted by Permana (2016) and Fahreza (2018), shows the results of brand ambassadors have a positive and significant effect on consumer purchasing decisions. Selection of the right brand ambassador can help capture potential markets that are targeted by the 
company and will encourage the creation of perceptions associated with brand ambassadors. It is common to find well-known celebrities chosen by companies to be their brand ambassadors. A celebrity is able to provide support for a related product or brand (Shimp, 2003). Based on previous research giving birth to the hypothesis:

\section{H3: Brand Ambassador has a positive and significant effect on Consumer Purchasing Decision}

H4: Brand Ambassador has a positive and significant effect on Brand Awareness

\section{H5: Brand Awareness has a significant positive effect on Consumer Purchasing Decision}

2.4 Empiric Model

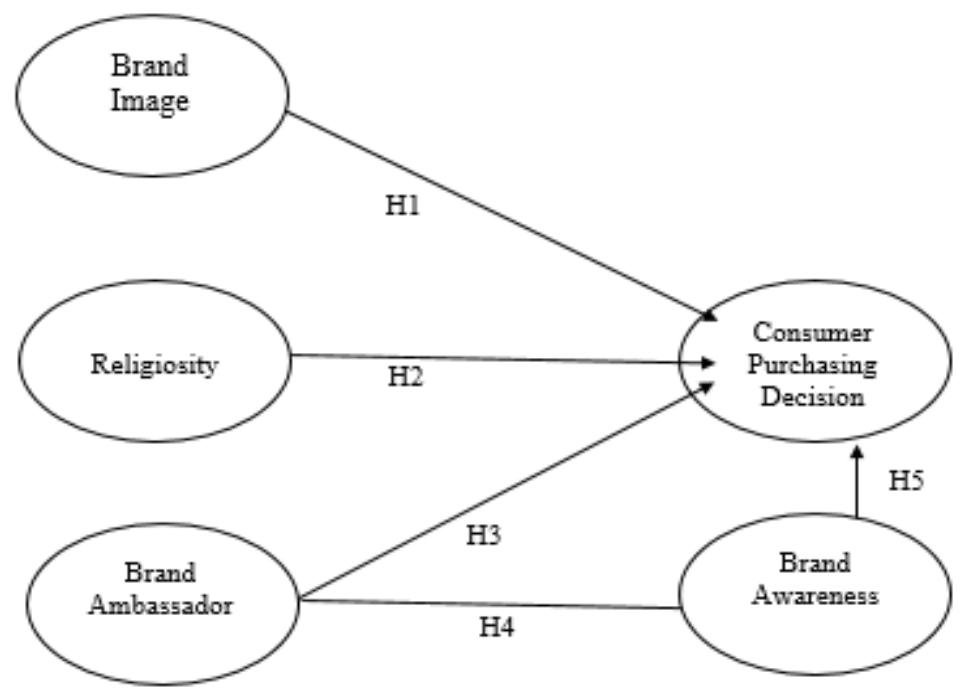

Figure1. Model of Consumer Purchasing Decision Improvement through Brand Image, Religiosity, and Brand Ambassador, with Brand Awareness as an intervening variable

\section{Method}

\subsection{Data}

The population of this research is all Tokopedia users in Central Java, Indonesia. The sample in this study is 150 samples from Tokopedia users in Central Java, because the population is too large and the coverage is too wide, it is not possible to collect data on the entire population. From the results of the questionnaire collection, data shows that the majority of Tokopedia users in Central Java are women with a number of 89 people (61\%), with ages between 21 and 25 years (36\%) and most often using the Tokopedia application 0 to 3 times each month $(80 \%)$.

\subsection{Measurement}

\section{Brand Image}

Brand image is a response that is formed in the minds of consumers or perceptions that are formed from previous information and experiences when hearing or seeing the brand name. Measurement of variables consists of 3 items, namely streghtness, uniqueness, and favorable (Prabowo, 2013). The indicator is measured using a Likert scale of $1=$ strongly disagree to $5=$ strongly agree. The test results show that the brand image variable has Croanbach's alpha value of 0.882 . So, it can be concluded that this study has met the reliability because it has a value above 0.7. Furthermore, it can be explained that the results of testing the composite reliability show good results because it has a composite reliability value of 0.927 . This shows that all indicators can be used as a measuring tool.

\section{Religiosity}

Religiosity is the extent to which a person is committed to his religion and is reflected in the attitudes and behavior of the individual. Measurement variables consist of 4 items, namely belief, experience, worship, and knowledge (Rahman et al., 2015). The indicator is measured using a Likert scale of $1=$ strongly disagree to $5=$ strongly agree. The test results show that the religiosity variable has Cronbach's alpha value of 0.893 . So, it can be concluded that this study has met the reliability because it has a value above 0.7 . Furthermore, it can be 
explained that the results of testing the composite reliability show good results because it has a composite reliability value of 0.926 . This shows that all indicators can be used as a measuring tool.

\section{Brand Ambassador}

Brand ambassadors are usually referred to as product ambassadors who serve as communicators and have an important role in conveying messages about a product that will be offered to consumers. Measurement variables consist of 4 items, namely, visibility, credibility, attraction, and power (Rossiter and Percy, 1987). The indicator is measured using a Likert scale of $1=$ strongly disagree to $5=$ strongly agree. The test results show that the brand ambassador variable has Cronbach's alpha value of 0.891 . So, it can be concluded that this study has met the reliability because it has a value above 0.7 . Furthermore, it can be explained that the results of testing the composite reliability show good results because it has a composite reliability value of 0.924 . This shows that all indicators can be used as a measuring tool.

\section{Brand Awareness}

Brand awareness is the customer's ability to recognize or remember that a brand is included in a particular product. A brand can be said to have equity if consumers recognize and remember a product brand outside of other products. Measurement variables consist of 3 items, namely, Top of Mind, Brand Recall, and Brand Recognition. The indicator is measured using a Likert scale of $1=$ strongly disagree to $5=$ strongly agree. The test results show that the brand awareness variable has Cronbach's alpha value of 0.859 . So, it can be concluded that this study has met the reliability because it has a value above 0.7. Furthermore, it can be explained that the results of testing the composite reliability show good results because it has a composite reliability value of 0.914 . This shows that all indicators can be used as a measuring tool.

\section{Consumer Purchasing Decision}

Consumer purchasing decision is a process where consumers choose two or more available alternative choices. The measurement of the variable uses 4 items, namely, product stability, product buying habits, giving recommendations to others, and making repeat purchases (Kotler and Keller, 2007). The indicator is measured using a Likert scale of $1=$ strongly disagree to $5=$ strongly agree. The test results show that the consumer purchasing decision variable has Cronbach's alpha value of 0.848 . So, it can be concluded that this study has met the reliability because it has a value above 0.7 . Furthermore, it can be explained that the results of testing the composite reliability show good results because it has a composite reliability value of 0.898 . This shows that all indicators can be used as a measuring tool.

\section{Results}

To test the proposed conceptual model including hypothesis testing, using the research tool Partial Least Squares Structural Equation Modeling (PLS-SEM) and the WarpPLS software.

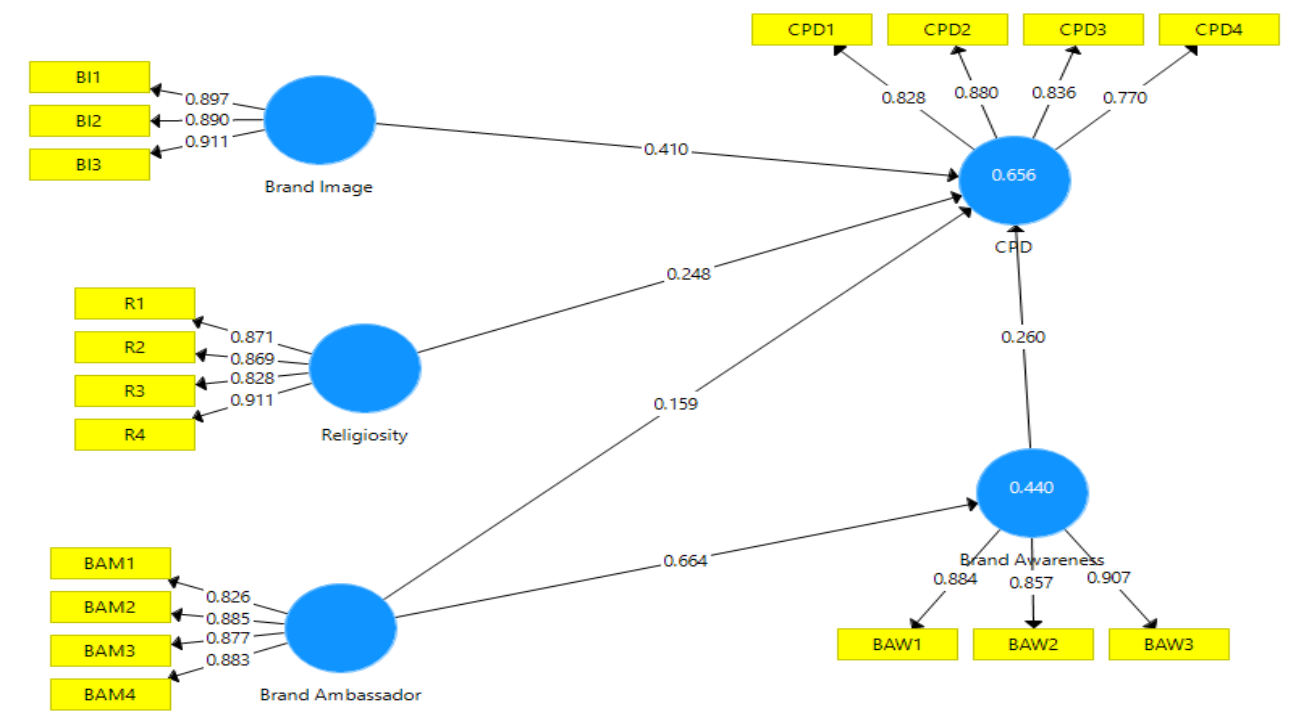

Figure 2. Goodness of Fit - Inner Model (Structural Model)

The goodness of fit of the structural model in the inner model was tested using the Predictive Relevance Value $\left(Q^{\wedge} 2\right)$. The value $\left(R^{\wedge} 2\right)$ of each endogenous variable in this study can be seen in Table 1. 
Table 1. R- Squared and Adjusted Value

\begin{tabular}{ccc}
\hline Endogen Variable & R-Square & $\begin{array}{c}\text { Adjusted } \\
\text { R-Square }\end{array}$ \\
\hline Brand Awareness (Y1) & 0.440 & 0.437 \\
\hline $\begin{array}{c}\text { Consumer Purchasing Decision } \\
\text { (Y2) }\end{array}$ & 0.656 & 0.647 \\
\hline
\end{tabular}

The variables $\mathrm{Y} 1$ and $\mathrm{Y} 2$ and show R-Square numbers of 0.440 and 0.656 , which indicate that the values are weak and moderate in predicting the model. Exogenous variables (brand ambassadors) predict the effect of endogenous variables (brand awareness) by $44 \%$. Meanwhile, exogenous variables (brand image, religiosity, brand ambassador and brand awareness) predict the effect of endogenous variables (consumer purchasing decisions) by $65.6 \%$. While the rest is influenced by other factors that are not included in the variables examined in this study.

Table 2. Outer Loading Value

\begin{tabular}{|c|c|c|c|}
\hline Variable & Indicator & $\begin{array}{c}\text { Outer } \\
\text { Loading }\end{array}$ & P-Value \\
\hline \multirow[t]{3}{*}{ Brand Image } & Strengthness & 0,897 & $<0,001$ \\
\hline & Uniqueness & 0,890 & $<0,001$ \\
\hline & Favorable & 0,911 & $<0,001$ \\
\hline \multirow[t]{4}{*}{ Religiosity } & Confidence & 0,871 & $<0,001$ \\
\hline & Experience & 0,869 & $<0,001$ \\
\hline & Worship & 0,828 & $<0,001$ \\
\hline & Science & 0,911 & $<0,001$ \\
\hline \multirow[t]{4}{*}{ Brand Ambassador } & Visibility & 0,826 & $<0,001$ \\
\hline & Credibility & 0,885 & $<0,001$ \\
\hline & Attraction & 0,877 & $<0,001$ \\
\hline & Power & 0,883 & $<0,001$ \\
\hline \multirow[t]{3}{*}{ Brand Awareness } & Top of Mind & 0,884 & $<0,001$ \\
\hline & Brand Recall & 0,857 & $<0,001$ \\
\hline & Brand Recognition & 0,907 & $<0,001$ \\
\hline \multirow[t]{5}{*}{ Consumer Purchasing Decision } & Product Stability & 0,828 & $<0,001$ \\
\hline & Habit of buying products & 0,880 & $<0,001$ \\
\hline & Provide other people's recommendations & 0,836 & $<0,001$ \\
\hline & Make repeat purchase & & \\
\hline & & 0,770 & $<0,001$ \\
\hline
\end{tabular}

From the results of table 2, which uses PLS, it shows that all indicator variable values in the study have a value greater than 0.5

\section{Partial Least Square (PLS) Analysis}

The direct effect of brand image on consumer purchasing decisions comes out with a coefficient value of 0.410 with a t-statistic value on this construct relationship is 4.706, so hypothesis 1 which states that Brand Image has a positive and significant effect on Consumer Purchasing Decision is accepted. This means that the higher the brand image, the higher the consumer purchasing decision. When consumers feel that this brand has an advantage over other brands, they will provide product recommendations to others. Furthermore, when consumers remember the brand, consumers will be more determined in choosing products. The results of data analysis in this study indicate a positive and significant relationship between brand image and consumer purchasing decisions. Supporting research (Rommy et al., 2018; Fianto et al., 2014; and Mutiara \& Madiawati, 2019) that brand image has a positive and significant impact on purchasing decisions. The higher the brand image in the minds of consumers, the higher the purchasing decision. A positive brand image will provide benefits for producers to be better known to consumers, or in other words, consumers will make choices to buy products that have a good brand image. And vice versa (Sangadji \& Sopiah, 2013).

The direct effect of religiosity on consumer purchasing decisions comes out with a coefficient value of 0.248 with the t-statistic value on this construct relationship is 2.420 . So, hypothesis 2 which states that Religiosity has a positive and significant effect on Consumer Purchasing Decision is accepted. Consumers who have good knowledge of their religion will always choose clear products and be careful about products with unclear benefits so that they can provide recommendations to others. Worship is something people do to show 
commitment to their religion. Islam views that goods or services have a use value in life because they support the implementation of worship to Allah SWT, so that consumers will be steady in choosing products that are useful or useless. The belief or creed in Islam shows the level of Muslim belief in the truth of the teachings of his religion. If consumers have high confidence that the product is good, they will make repeat purchases. This means that the better the religiosity, the better the consumer purchasing decision will be. Conversely, if religiosity decreases, then consumer purchasing decisions will also decrease. In line with Sutrisno (2013), that as a Muslim, in making purchasing decisions and buying an item to be used, it must be considered whether the goods consumed provide benefits or not.

The direct effect of brand ambassador on consumer purchasing decisions comes out with a coefficient value of 0.159 with the t-statistic value on this construct relationship is 1.986 . So, hypothesis 3 which states that Brand Ambassador has a positive and significant effect on Consumer Purchasing Decision is accepted. This study supports previous research conducted by Logica and Magdalena (2015), regarding the influence of brand ambassadors on international brand image and its impact on purchasing decisions. With the presence of brand ambassadors or artists who are known by the wider community to promote these products, this is a special attraction for consumers to follow everything that the artist does, so that consumers will make purchase decisions.

The direct influence of brand ambassadors on brand awareness comes out with a coefficient value of 0.664 with the t-statistic value on this construct relationship is 10.390. So, hypothesis 4 which states that Brand Ambassador has a positive and significant effect on Brand Awareness is accepted. The more brand ambassadors have the credibility of trust to convey a good brand to the public, the more the brand will be remembered or be the first to be remembered by consumers. If a celebrity has the ability to attract consumers to buy, the consumer will have a minimum level of brand recognition or brand awareness. Attraction, the higher the level of people's liking to a celebrity, the unaided brand recall will increase. Which means that the higher the brand ambassador, the higher the brand awareness. Conversely, if the brand ambassador decreases, the brand awareness will also decrease. The results of this hypothesis are accepted and support the research conducted by Hamid (2013) which shows that brand ambassadors have a positive and significant effect on brand awareness. This means that the more effective the use of artists as brand ambassadors in promotional activities for a brand, the higher the level of public awareness of the brand.

The direct effect of brand awareness on consumer purchasing decisions comes out with a coefficient value of 0.260 with the t-statistic value on this construct relationship is 2.767 . So, hypothesis 5 which states that Brand Awareness has a positive and significant effect on consumer purchasing decisions is accepted. Consumers will tend to buy products if they already know the brand rather than not knowing the brand. Which means that the better the brand awareness, the better the consumer purchasing decision will be. Conversely, if brand awareness decreases, consumer purchasing decisions will also decline. The results of this research hypothesis are accepted and support previous research conducted by Berryman and Kavka (2017), that brand awareness influences purchasing decisions.

Table 3. Results of Indirect Influence Statistics

\begin{tabular}{lccc}
\hline Indirect effects & Path Coefficient & $\begin{array}{c}\text { T Statistics } \\
(\mid \mathbf{O} / \text { STDEV } \mid)\end{array}$ & P Values \\
\hline BAM -> BAW -> CPD & 0.173 & 2.513 & 0.012 \\
\hline
\end{tabular}

Table 3 shows a positive path coefficient value of 0.173 and a significant p-value of $0.012<0.05$, which means that the brand awareness variable is an intervening variable for brand ambassador and consumer purchasing decisions. Brand awareness is an intervening variable so that it can mediate the variable brand image on consumer purchasing decisions. In line with research (Untono, 2016) which states that brand awareness mediates the relationship between brand ambassadors and consumer purchasing decisions. This can be interpreted that consumers have a view that the product or brand used by a celebrity as a brand ambassador has very good credibility, so the brand owned by a company is also very good, besides that the attribute of brand awareness of a brand is a brand. products and remembering brand names also greatly influence consumer purchasing decisions. Consumer perceptions that lead to the credibility of celebrity brand ambassadors and brand awareness are what then make purchasing decisions can increase.

In addition, the celebrity credibility of brand ambassadors also plays an important role in creating brand 
awareness for consumers. The credibility of brand ambassadors encourages consumers to pay more attention to the brand of a product and choose products. The effect of brand awareness causes consumers to have a positive attitude towards the brand. Consumers also have a fairly high knowledge of brands that make purchasing decisions tend to be positive. Not only must the credibility of brand ambassadors be considered, but brand awareness must also be maintained so that purchasing decisions can increase.

\section{Conclusion and Implication}

Based on the discussion that has been done in the previous chapters on the results of this study, it can be concluded that Brand Ambassador is an important factor in determining brand awareness. Tokopedia has good brand ambassadors, which will make it easier for them to create brand awareness in the minds of consumers. To increase good consumer purchasing decisions at Tokopedia requires brand image, religiosity, brand ambassador and brand awareness. In addition to determining brand awareness, brand ambassador variables directly influence consumer purchasing decisions. Brand awareness plays a very important role as a mediation in the relationship between brand ambassadors and consumer purchasing decisions, which means that brand awareness has a direct influence between brand ambassadors and consumer purchasing decisions.

The managerial implication that is expected to increase consumer purchasing decisions on Tokopedia is to increase a positive brand image for consumers, Tokopedia is advised to increase favorable or brand preferences, trust, and feelings of brand friendship. As well as maintaining uniqueness to differentiate one brand from another In addition, to increase religiosity, Tokopedia users are advised to increase their confidence and maintain the experience. Technology is increasingly sophisticated today, making e-commerce more prevalent which aims to make it easier for people to shop online, but when shopping online this creates a lot of uncertainty, doubt, or actions that aim to harm others (gharar). Furthermore, to reduce various speculations - speculation that is not clear about the products sold on Tokopedia, Tokopedia must provide a clear SOP (Standard Operating Procedure) SOPs are defined as clear payment methods, sales of legal goods, increased consumer rights to return goods (returns) if the goods received are different from the product description (guarantee of return of goods and money), clear delivery tracking, and so on. So that the confidence that consumers have in Tokopedia will increase. To increase brand ambassadors that are good for consumers, Tokopedia is advised to increase visibility so that it creates great attention to a celebrity. And maintain credibility. And finally, to increase good brand awareness in consumers, Tokopedia is recommended to increase brand recall so that consumers can easily remember brands based on product categories and maintain top of mind so that Tokopedia will always be the first brand that appears in the minds of consumers.

The limitation in this study is that the R-Square value on the variable brand awareness and consumer purchasing decisions is still low, so the influence of other variables still needs to be investigated. And the time for distributing the questionnaire was very short so that the sample size was relatively small, namely 150 . Not many open questions in the questionnaire were filled in by respondents so the results did not describe the real situation. On the agenda for further research, the researcher suggests that Brand awareness can be investigated more deeply because the R-Square value is still low. Other variables such as brand association can be used to examine the impact or influence between variables. Further research can use interview or observation techniques so that the data obtained is more representative of the actual situation in the population and sample under study

\section{References}

Aghekyan-Simonian, et. al (2012). The role of product brand image and online store image on perceived risks and online purchase intentions for apparel. Journal of Retailing and Consumer Services, 19(3). https://doi.org/10.1016/j.jretconser.2012.03.006

Al-Goaib, S. (2003). Religiosity and social conformity of university students: An analytical study applied at King Saoud University. Arts Journal of King Saoud University, 16(1), 51-99.

Aliman, N. K. et. al. (2018). Religiosity Commitment and Decision-Making Styles Among Generation Y Muslim Consumers in Malaysia. International Journal of Academic Research in Business and Social Sciences, 8(1), 554-576. https://doi.org/10.6007/IJARBSS/v8-i1/3830

Ambroise, L. et. al. (2014). From endorsement to celebrity co-branding: Personality transfer. Journal of Brand Management, 2l(4), 273-285. https://doi.org/10.1057/bm.2014.7

Ansari, A., Mela, C. F., \& Neslin, S. A. (2008). Customer channel migration. Journal of marketing research, 45(1), 60-76. https://doi.org/10.1509/jmkr.45.1.60

Anwar, A., Gulzar, A., Sohail, F. B., \& Akram, S. N. (2011). Impact of brand image, trust, and affect on consumer brand extension attitude: the mediating role of brand loyalty. International Journal of Economics 
and Management Sciences, 1(5).

Berryman, R., \& Kavka, M. (2017). 'I guess a lot of people see me as a big sister or a friend': The role of intimacy in the celebrification of beauty vloggers. Journal of Gender Studies, 26(3), 307-320. https://doi.org/10.1080/09589236.2017.1288611

Bian, X., \& Moutinho, L. (2011). The role of brand image, product involvement, and knowledge in explaining consumer purchase behaviour of counterfeits: direct and indirect effects. Eur. J. Mark., 45(1/2), 191-216. https://doi.org/10.1108/03090561111095658

Botha, E., \& Mills, A. J. (2012). Managing the new media: Tools for brand management in social media. In: A. Close (Ed.), Online consumer behavior: Theory and research in social media, advertising and E-tail (pp. 83-100). New York: Taylor \& Francis.

Brewer, A., \& Zhao, J. (2010). The impact of a pathway college on reputation and brand awareness for its affiliated university in Sydney. International Journal of Educational Management. https://doi.org/10.1108/09513541011013033

C. Kurzman, et. al . (2007). Celebrity Status. Sociological Theory, 25(4), 347-367. https://doi.org/10.1111/j.1467-9558.2007.00313.x

Doucett, E. (2008). Creating Your Library Brand, Communicating Your Relevance and Value to Your Patrons. Chicago: American Library Association (E-books).

Dwivedi, et. al. (2015). Social media marketing and advertising. The Marketing Review, 15(3), 289-309. https://doi.org/10.1362/146934715X14441363377999

Elaziz, M. F., \& Kurt, A. (2017). Religiosity, consumerism and halal tourism: A study of seaside tourism organizations in Turkey. Turizam: međunarodni znanstveno-stručni časopis, 65(1), 115-12

Engelland, B. T. (2014). Religion, humanism, marketing, and the consumption of socially responsible products, services, and ideas: Introduction to a special topic section. Journal of Business Research, 67(2), 1-4. https://doi.org/10.1016/j.jbusres.2013.03.005

Esso, N., \& Dibb, S. (2004). Religious contrasts in consumer decision behavior. European Journal of Marketing, 28(5), 36-53.

Fahreza, M. D. (2018). Analysis of the effect of product quality, brand ambassador, and the attractiveness of promotion towards purchasing decisions with brand image as intervening variables.

Fianto, A. Y. A. et. al. (2014). The influence of brand image on purchase behaviour through brand trust. business management and strategy, 5(2), 58. https://doi.org/10.5296/bms.v5i2.6003

Habibah, U., \& Sumiati. (2016). The influence of brand awareness and brand image on purchase decision (Study on aqua consumers in administrative science faculty brawijaya university class of 2013). Jurnal Ekonomi Dan Bisnis, 1(1), 1-8.

Hamid, F. Z., \& T. Hartati. (2013). The effect of using celebrity endorser and jingle in Mentari Television Advertisement (Indosat) on brand awareness of employees in Beji Depok. Epigram, 10(2), 80-88.

Hill, P. C., \& Pargament, K. I. (2003). Advances in the conceptualization and measurement of religion and spirituality: Implications for physical and mental health research. American psychologist, 58(1), 64. https://doi.org/10.1037/0003-066X.58.1.64

Homburg, C., Klarmann, M., \& Schmitt, J. (2010). Brand awareness in business markets: When is it related to firm performance? International Journal of Research in Marketing, 27(3), 201-212. https://doi.org/10.1016/j.ijresmar.2010.03.004

Kalamas, M., Cleveland, M., \& Laroche, M. (2014). Pro-environmental behaviors for thee but not for me: Green giants, green Gods, and external environmental locus of control. Journal of Business Research, 67(2), 12-22. https://doi.org/10.1016/j.jbusres.2013.03.007

Karam, A. A., \& Saydam, S. (2015). An analysis study of improving brand awareness and its impact on consumer behavior via media in North Cyprus (A case study of fast food restaurants). International Journal of Business And Social Science, 6(1).66-80.

Keller, K. L. (2003). Strategic Brand Management. Prentice - Hall.

Kim, K. H. et. al. (2008). Brand equity in hospital marketing. Journal of Business Research, 61(1), 75-82. https://doi.org/10.1016/j.jbusres.2006.05.010 
Kotler and Keller. (2007). Manajemen Pemasaran, Edisi 12, Jilid 1, PT.Indeks, Jakarta Alma, Buchori. 2008. Manajemen pemasaran dan pemasaran jasa. Bandung: Alfabeta.

Kotler, P., \& Gary, A. (2008). Prinsip-prinsip Pemasaran. Edisi 12. Jilid 1. Jakarta: Erlangga

Kotler, P., \& Keller, (2005). Manajemen Pemasaran, Jilid I, Edisi Kedua belas, Jakarta: PT. Indeks

L. Ambroise, et. al. (2014). From endorsement to celebrity co-branding: Personality transfer. Journal of Brand Management, 273-285. https://doi.org/10.1057/bm.2014.7

L. de Chernatony. (2001). A model for strategically building brands. Brand Management, 9(1), 32-44. https://doi.org/10.1057/palgrave.bm.2540050

Latiff, Z. A. B., Rezai, G., Mohamed, Z., \& Amizi Ayob, M. (2016). Food labels' impact assessment on consumer purchasing behavior in Malaysia. Journal of food products marketing, 22(2), 137-146. https://doi.org/10.1080/10454446.2013.856053

Lau, T. C. (2010). Towards socially responsible consumption: an evaluation of religiosity and money ethics. International Journal of Trade, Economics and Finance, 1(1), 32-35. https://doi.org/10.7763/IJTEF.2010.V1.6

Liu, W., \& Aaker, J. (2008). The happiness of giving: The time-ask effect. Journal of consumer research, 35(3), 543-557. https://doi.org/10.1086/588699

Logica, B., \& Magdalena, R. (2015). Using big data in the academic environment. Procedia Economics and Finance, 33, 277-286. https://doi.org/10.1016/S2212-5671(15)01712-8

McDaniel, S. W., \& Burnett, J. J. (1990). Consumer religiosity and retail store evaluative criteria, Journal of the Academy of Marketing Science, 18, 101-112. https://doi.org/10.1007/BF02726426

Moschis, G. P., \& Ong, F. S. (2011). Religiosity and consumer behavior of older adults: a study of subcultural influences in Malaysia. Journal of Consumer Behaviour, 10(1), 8-17. https://doi.org/10.1002/cb.342

Mutiara, \& Madiawati, P. N. (2019). Effect of electronic word and brand image on purchase decisions in Nature Republic Aloe Vera 92\% Soothing Gel. E-Proceeding of Management, 6(1), 1099-1106.

Permana, S. I. (2016). The influence of product quality and brand ambassadors on brand image and its impact on purchase decisions on Relic Distro Di Syndicate. Manajemen. Fakultas Ekonomi. Universitas Pasundan Bandung.

Prabowo, A. (2013). Analysis of the effect of product quality, brand trust, brand image and customer satisfaction on brand loyalty in aqua mineral water (A case study on aqua mineral water consumers in South Tangerang Area). Final Project: Universitas Islam Negeri Syarif Hidayatullah Jakarta.

Qualman, E. (2010). Social media revolution 2 (refresh). Socialnomics-Social Media Blog, 5.

R. Yogi Prawira, Slamet mulyana, and Teddy kurnia wirakusumah. 2012. The relationship between the characteristics of the Honda spacy helmet-in brand ambassador with the stages of consumer purchasing decisions. E-jurnal Mahasiswa Universitas Padjajaran, 1(1).

Rahi, S. (2015). Moderating role of brand image with relation to internet banking and customer loyalty: a case of branchless banking. The Journal of Internet Banking and Commerce, 20(3). https://doi.org/10.4172/1204-5357.1000131

Rahman, et. al. (2015). Assessing knowledge and religiosity on consumer behavior towards halal food and cosmetic products. International Journal of Social Science and Humanity, 5(1), 10. https://doi.org/10.7763/IJSSH.2015.V5.413

Razzaque, M. A., \& Chaudhry, S. N. (2013). Religiosity and Muslim consumers' decision-making process in a non-Muslim society. Journal of Islamic Marketingô, 4(2), 198-217. https://doi.org/10.1108/17590831311329313

Rommy, A. S. N., Moh, N. B. H. H., \& Nur, A. R. Y. N. (2018). Effect of brand image and price perception on purchase decision. Journal of Business and Management, 20(8), 76-81. https://doi.org/10.9790/487X-2008027681

Rossiter, J. R., \& Percy, L. (1987). McGraw-Hill series in marketing.Advertising and promotion management. Mcgraw-Hill Book Company.

Ryu, K., Han, H., \& Kim, T. H. (2008). The relationships among overall quick-causal restaurant image, 
perceived value, customer satisfaction, and behavioral intentions. International Journal of Hospitality Management, 27(3), 459-469. https://doi.org/10.1016/j.ijhm.2007.11.001

S. S. Alam, R. Mohd, \& B. Hisham. (2001). Is religiosity an important determinant on Muslim consumer behavior in Malaysia? Journal of Islamic Marketing, 2(1), 83-96. https://doi.org/10.1108/17590831111115268

Samosir, L. S. (2016). The influence of the use of brand ambassador "Dewi Sandra" on the purchase decision of Wardah cosmetics consumers in Bandung. Jurnal Sosioteknologi, 15(2), 233-240. https://doi.org/10.5614/sostek.itbj.2016.15.02.6

Sangadji, E. M., \& Sopiah. (2013). Consumer behavior: a practical approach accompanied by the Association of Research Journals. Yogyakarta: Andi Offset.

Schiffman \& Kanuk. (2008). Consumer Behaviour (7th ed.). Jakarta : PT Indeks

Shabbir, M. Q., Khan, A. A., \& Khan, S. R. (2017). Brand loyalty brand image and brand equity: the mediating role of brand awareness. International journal of innovation and applied studies, 19(2), 416.

Shen, H., Yuan, Y., Zhang, Q., \& Zhao, J. (2014). An empirical study of customer-based brand equity model for China economy hotels. Journal of China Tourism Research, 10(1), 21-34. https://doi.org/10.1080/19388160.2013.861778

Shimp, T. A. (2003). Promotional Advertising Additional Aspects of Integrated Marketing Communication Volume 5, was translated by Revyani Syahrian and Dyah Anikasari, Erlangga, Jakarta.

Shukor, S., \& Jamal, A. (2013). Developing Scales for Measuring Religiosity in the Context of Consumer Research. Middle-East Journal of Scientific Research 13 (Research in Contemporary Islamic Finance and Wealth Management), 69-74.

Supriyadi, F. Y., \& Indra, G. K. (2016). The influence of product quality and brand image on purchase decisions (study on students using converse brand shoes at Fisip Merdeka University). Jurnal Bisnis Dan Manajemen, $3(1), 1$.

Sutrisno, R. (2013). Muslim consumer behavior: perception of religiosity and perception of product attributes on loyalty of halal labeled food and beverage products among Muslim students in Bandung. Jurnal Sigma- Mu, 5(2). Diakses pada tanggal 25 maret 2019, pukul 01: 56 WIB, pada URL

Sweeney, J., \& Swait, J. (2008). The effects of brand credibility on customer loyalty. J. Retail. Consumer Serv., 15(3), 179-193. https://doi.org/10.1016/j.jretconser.2007.04.001

The Brand Ambassadors. (2012). Advertising Age, 83(45), 5-5.

Tjiptono. (2014). Service Marketing Principles, Applications and Research. Andi: Yogyakarta.

Tsiotsou, R. H., \& Wirtz, J. (2015). The three-stage model of service consumption. In Handbook of Service Business. Edward Elgar Publishing. https://doi.org/10.4337/9781781000410.00015

Untono, S. A. (2016). The influence of JKT48 celebrity endorser credibility on purchase intention with brand awareness as a mediation variable on Honda Beat motorcycles in Malang city. Jurnal Parsimonia, 2(3), 101-111.

Valkenburg, P. M., \& Buijzen, M. (2005). Identifying determinants of young children's brand awareness: Television, parents and pers. Applied Developmental Psychology, 26(4), 456-468. https://doi.org/10.1016/j.appdev.2005.04.004

Van Boxstael, S. et.al. (2014). Understanding and attitude regarding the shelf life labels and dates on pre-packed food products by Belgian consumers. Food Control, 37, 85-92. https://doi.org/10.1016/j.foodcont.2013.08.043

Wang, F., \& Hariandja, E. S. (2016). The Influence of brand ambassador on brand image and consumer purchasing decision: A case of Tous Les Joursin Indonesia. In International Conference on Entrepreneurship (IConEnt-2016).

Wijayanti, L., Fransisca, F., \& Ivana, I. (2010). Evaluation of Inventory Information System Control at PT. Ginsa Inti Pratama (Doctoral dissertation, BINUS).

Wulandari, R. et. al. (2012). Characteristic and preferences of green consumer stratification as bases to formulating marketing strategies of eco label-certified furniture. https://doi.org/10.22164/isea.v6i1.67 
Zeithaml, V. A. (1988). Consumer perceptions of price, quality, and value: a means-end model and synthesis of evidence. Journal of marketing, 52(3), 2-22. https://doi.org/10.1177/002224298805200302

Zhang, Y. (2015). The impact of brand image on consumer behavior: A literature review. Journal of business and management. https://doi.org/10.4236/ojbm.2015.31006

\section{Copyrights}

Copyright for this article is retained by the author(s), with first publication rights granted to the journal.

This is an open-access article distributed under the terms and conditions of the Creative Commons Attribution license (http://creativecommons.org/licenses/by/4.0/). 